\title{
Augustus Polonus. The Image of the Emperor in Polish Historiography in Inter-War Period: Preliminary Remarks
}

\begin{abstract}
Tn this paper I would like to examine the image of the first Roman emperor presented in the Polish historiography in the inter-war period. This issue has been dealt with in three main aspects: the cult of an emperor, the eschatological approach presented by Tadeusz Zieliński and the description of Augustus' anniversary (1937). I will limit my remarks to three most prominent scholars in this field of research in the inter-war Poland: the above-mentioned Tadeusz Zieliński, Ludwik Piotrowicz and Mieczysław Stanisław Popławski. Polish historiography of antiquity is not well recognized and it is my intention to try to present the basic information about the most eminent Polish inter-war period scholars who in their works devoted a lot of attention to the figure of Augustus ${ }^{1}$.
\end{abstract}

\footnotetext{
${ }^{1}$ For about twenty years the history of studies on the ancient world has been one of the most important subject area in Altertumswissenschaften. Although I limited myself mainly to the field of the history of the Roman religion I would like to indicate further references: Franz Cumont et la science de son temps, [in:] Mélanges de l'Ecole française de Rome. Italie et Méditerranée, Rome 1999; C. BonNET, 'L'Histoire séculière et profane des religions' (F. Cumont): Observations sur l'articulation entre rites et croyance dans l'historiographie des religions de la fin du XIX et de la première moitié du XX siècle, [in:] Rites et croyances dans le religions du monde romain. Entretiens sur l'antiquité classique, vol. LIII, Vandoeuvres-Genève 2007, p. 1-28; Les religions orientales dans le mond grec et romain cent ans aprés Cumont (1906-2006). Bilan historique et historiographique, ed. C. Bonnet, V. Pirenne-Delforge, D. Praet, Brussels-Rome 2009; monographical issue of ARg 5, 2003 devoted to Georg Wissowa; V.S. Severino, La religione di questo mondo di Raffaele Pettazzoni, Roma 2009; C. SANTI, La religione romana negli studi di $R$. Pettazzoni, SASL 24, 2009, p. 173-188. Extremely interesting data on the ways of transmission of knowledge are to be found in the collections of the letters between scholars: D. AcCorinti, Herbert Jennings Rose (1883-1961). The Scholar and his Correspondents, ICS 33/34, 2008/2009, p. 65-107; D. AcCorinti, Raffaele Pettazzoni and Herbert Jennings Rose, Correspondence 1927-1958. The Long Friendship between the Author and the Translator of The All-knowing God, Leiden-Boston 2014; Mongolus Syrio salutem optimam dat: La Correspondance entre Mikhaïl Rostovtzeff et Franz Cumont, ed. G. Bongard-Levine, C. Bonnet, Y. Litvinenko, A. Marcone, Paris 2007; S'écrire et écrire sur l'Antiquité. L'apport des correspondances à l'histoire des travaux scientifiques, ed. C. Bonnet, V. KRINGs, Grenoble 2008. The correspondence of Tadeusz Zieliński is partly published: H. GeremeK, Deux lettres adressées à M. Rostovtseffen 1933, DHA 18, 1992, p. 15-25; Listy do Stefana Srebrnego, ed. G. Golik-Szarawarska, Warszawa 1997; Tadeusz Zieliński (1859-1944). Spuren und
} 
The first researcher whose output in this field I would like to discuss is Tadeusz Zieliński, one of the greatest experts on the European antiquity of the first half of the $20^{\text {th }}$ century ${ }^{2}$. His academic achievements were commonly accepted - not only in Poland. He was awarded honoris causa doctorates by the universities in Moscow (on the occasion of the $25^{\text {th }}$ anniversary of his research work), Athens, Groningen, Oxford, Vilnius, Warsaw, Cracow, Poznań, Lviv, Brno, Paris and Brussels. He was a member of numerous academies, e.g. the Bavarian, the British and Accademia dei Lincei in Rome ${ }^{3}$. His well-known studies dealt with the Old Attic Comedy, Homeric psychology and Cicero's speeches as well as his influence over the ages ${ }^{4}$. His works on the history of ancient religion were less popular although in my opinion Zieliński's views on Roman religion were undervalued. At this point I would only like to sketch the basic characteristics of his views on this subject. His ideas can be compared only to the work of Franz Cumont, who cannot be omitted in this regard.

Zieliński treated the development of Roman religion not in terms of "organic development" but what he proposed instead was the description of three directions of its development: the "national", the "Greek" and the "Eastern" direction. Zieliński endeavoured to show the "psychology" of religious feelings. He tried to understand the religious experience of the Greco-Romans by writing on something more than merely the cult practices and acts as it had been done so far - suffice to mention the classic book Religion und Kultus der Römer of Georg Wissowa ${ }^{5}$. As Zieliński himself admitted, the first approach to the interpretation of the beliefs of ancient Romans was created as a kind of supplement to this work. He considered the way of thinking about Roman religion presented by German scholar as a climax of previous research in this field and as a starting point for further studies - although he noticed certain deficiencies there. That is why the first larger study by Zieliński devoted to Roman religion was considered to be the supplement to the Wissowa's magisterial book presenting the elements which the German scholar had omitted - namely the psychological background ${ }^{6}$. Wissowa criticized

Zeugnisse seines Lebens und Wirkens aus süddeutschen Beständen, ed. U. Dubielzig, Toruń 2009; Tadeusz Zieliński (1859-1944). W 150 rocznicę urodzin, ed. E. Olechowska, Warszawa 2011. Some other studies on history of Altertumswissenschaften are quoted below.

${ }^{2}$ Cf. T. Zieliński, Mein Lebenslauf - Erstausgabe des deutschen Originals - und Tagebuch 1939-1944, ed. J. Axer, A. Gavrilov, M. von Albrecht, Frankfurt am Main-Berlin-Bern et al. 2002, p. 51-146. Short introduction to Zieliński’s life and work: A. Gillmeister, The Point of View. Tadeusz Zieliński on Ancient Religions, Warsaw 2013 (Akme. Studia historica, 11).

${ }^{3}$ Zieliński's academical achievements are enlisted in Tadeusz Zieliński (1859-1944). Spuren und Zeugnisse..., p. 171-176.

${ }^{4}$ E.g. T. ZielińsKi, Die Gliederung der altattischen Komödie, Leipzig 1885; IDEM, Das Clauselgesetz in Ciceros Reden, Leipzig 1904; IDEM, Der constructive Rhythmus in Ciceros Reden, Leipzig 1914; IDEM, Cicero im Wandel der Jahrhunderte, Leipzig 1897 ( th $^{\text {th }}$ edition: Stuttgart 1967).

${ }^{5}$ G. Wissowa, Religion und Kultus der Römer, München 1912 .

${ }^{6}$ T. Zieliński, Rom und seine Gottheit, München 1903 (= T. Zieliński, Iresione tomus II. Dissertationes ad antiquorum religionem spectans continens, Leopoli 1936, p. 111-153. I refer to this edition). 
Zieliński's ideas rather strongly for their excessive psychologisation ${ }^{7}$. Undoubtedly, Zieliński was aware of the role of a ritual in ancient religions but according to him the essence of religion was perceptible only when a ceremony was perceived with respective feelings. He also believed that if a contemporary reader lit in himself a bright torch of religious feeling, he would get the direct access to the spiritual experience of the ancients. He included this assumption in the third axiom of his six-point methodology which he published at the beginning of each part of the series Religions of the ancient world, the consummation of his research on ancient religions ${ }^{8}$. He believed that the inborn religious experience which lies in the human nature and not in an image is the proto-source of religion as such. Nevertheless it cannot be concealed that Zieliński sometimes seemed to forget that religion is also a historical phenomenon which undergoes development and change. The difference in perspective between Zieliński and Wissowa (and also Theodor Mommsen) is remarkable9.

One important note for the further discussion should be highlighted. Tadeusz Zieliński's views were marked by deep Christocentricity. To him Christian religion was the acme of humanity pursuits whereas ancient religion - the right Old Testament of this Christianity ${ }^{10}$.

How did Tadeusz Zieliński's views relate to the cult of an emperor considering this background? At this point it is worth making one more remark on Zieliński's understanding of Roman religion - the fact that under the influence of Schopenhauer's philosophy he defined religion as an ingredient of the common Will in its various manifestations and particular deities were considered as the objectification of that Will. A Roman deity was single in a plurality and plural in a singularity. He saw the genesis of the cult of an emperor in the cult of genii who were thought to be a particle of a deity. The particle which manifested itself in an individual will and the genius of the Roman people was the highest emanation of the collective will ${ }^{11}$.

\footnotetext{
${ }^{7}$ G. Wissowa, Religion..., p. 17. More on the topic: A. Gillmeister, The Point of view..., p. 44-46.

${ }^{8}$ The cycle is composed of six parts: history of Greek religion (Petrograd 1917; Polish tr. 1921, English tr. 1926, French tr. 1926), history of Hellenistic religion (Petrograd 1922; Polish tr. 1925) and published only in Polish: comparison of Hellenism and Judaism (vol. I-II, Warsaw 1927); religion of Roman Republic (vol. I-II, Warsaw 1933-1934) and volumes about religion in Roman empire and ancient Christianity, published from the manuscript at the end of $20^{\text {th }}$ century (Torun 1999).

${ }^{9}$ Cf. A. Momigliano, Religious History without Frontiers: J. Wellhausen, U. Wilamowitz, and E. Schwartz, HT 21, 1982, p. 49-64; C. Frateantonio, Konzepte der Independenz von Religion, Stadt und Recht bei Theodor Mommsen und Georg Wissowa, ARg 5, 2003, p. 41-46; and also J.-L. DurAnD, J. ScheID, "Rites" et "religion". Remarques sur certains préjugés des historiens de la religion des Grecs et des Romains, ASSR 85, 1994, p. 23-43. T. Zieliński seemed to anticipate, at least partly, the point of view of French scholars who seemed to be inspired by structuralism.

${ }^{10} \mathrm{He}$ used those expressions in six Axioms, the formulation of which was the achievement of his life and his scientific credo. They were published at the beginning of every volume of the religious series, cf. A. Gillmeister, The point of view..., p. 14-15.

${ }^{11}$ T. ZielińsKi, Rom..., p. 114-115.
} 
Thus in 7 BC by setting up the statue of his own genius in shrines of the lares compitales $^{12}$ Augustus replaced the genius of the people as the manifestation of the collective will of Quirites. This did not mean the deification of the emperor, which Zieliński clearly stressed, but it contributed to the concentration in the cult of Augustus' genius of which the emperor was the highest embodiment ${ }^{13}$. Hence the celebration of Virtuti Augustae or Pietati Augustae, which in abstract terms he called Augustianisation. In this regard Zieliński explicitly stated that this form of the cult concerned the living ruler or, to be more precise, his deity and not himself. It was also supposed to be more important than the celebration of divorum, that is posthumously deified emperors. Consecratio divorum was based on the belief that the dead emperors were fortes et boni. This in turn gave partly ethical character to hitherto juridical state religion because apotheosis thought to be the reward for merit. As we can see Zieliński did not fully free himself from Mommsenian mode of thinking on religion and law. Zieliński treated posthumous deification of emperors as the consequence of the Republican cult of deorum Manium which, as he believed, was the expansion of the cult of dead ancestors. The fact is that since Augustus' times each emperor as the head of the state was perceived as the father of the whole nation. Zieliński believed that the cult of an emperor had its roots in the Republican religion and not in Greece. At that time this was a new assumption that opposed the views which treated Roman religion as a poor comparison to the Greek religion and dated the cult of a ruler back to Alexander the Great perceiving this issue only in political terms. Zieliński also noticed changes in the cult of rulers though he tried to marginalise them. Analysing the genesis of the cult Zieliński omitted the figure of Julius Caesar, because he thought his deification to be exceptional. He did not try to determine when this deification took place. He considered Augustus as the actual creator of this type of the cult. $\mathrm{He}$ devoted to Augustus a considerable part of his research especially in the context of the eschatological examination about which I will write below. Zieliński saw the roots of the cult of a ruler in the Republican religion and not in Greece, which made his views original especially in Poland. He also noticed changes in the cult of an emperor, that is transition from the veneration of Augustus as a god after his death to the veneration of the living emperor, though he did not attach much importance to them ${ }^{14}$.

The next Polish scholar who dealt with the problem of emperors' divinity was Ludwik Piotrowicz (1886-1957). He was the head of the department of the ancient history at the University of Poznań and then he took up position at the Jagiellonian

\footnotetext{
${ }^{12}$ About significance of Augustus' reform see: G. Wissowa, Religion..., p. 70.

${ }^{13}$ T. ZielińsKi, Rom..., p. 140-141.

${ }^{14}$ T. ZIELIŃsKi, Religia cesarstwa rzymskiego [Religion of the Roman Empire], Toruń 1999, p. 149-199 is the most complex presentation of Zieliński's view on the subject. Compare in short: T. ZIELIŃsKI, Rom..., p. 139-145. About the circumstances in which he wrote this fragment cf. A. Gillmeister, The Point of view..., p. 13-14.
} 
University in Kraków. He also treated Augustus as a basis for a more elaborate discussion. While he worked in Poznań, he wrote a comprehensive study The cult of a ruler in antiquity ${ }^{15}$. Piotrowicz, whose academic interests were not limited only to the classical antiquity but also included the history of the Middle East, treated the subject in a holistic manner. The question of the Roman cult of an emperor was only a part of his research. Piotrowicz, a student of a Cracovian philologist Kazimierz Morawski, supplemented his education by studying in Berlin. It should be noted that the influences of the German scholars of the first years of the $20^{\text {th }}$ century are strongly visible in his research, e.g. in treating Roman religion as an official and ritual form and in emphasising its politicisation ${ }^{16}$. It is easy to point out the sources of his inspiration such as the works of Eduard Meyer (whose student Piotrowicz was) and Ernst Kornerman. It corresponded to the contemporary understanding of the Roman culture as poorer and ectypal in comparison to what had been created by the Greeks. In the part of this study which he devoted to Rome, Piotrowicz presented an opinion that the cult of an emperor was another argument proving Hellenisation of Roman religion. The pattern began with the veneration of Alexander the Great, which took place in the Greek East. Therefore the veneration of Roman emperors was a consecutive political step in the development of the cult of rulers. In this respect the honours given to Caesar were, according to Piotrowicz, nothing more than a political act which was to help to legalise the exceptional position of the dictator on the Roman political arena. Piotrowicz having been inspired by German scholars and Zieliński's ideas, linked in a quite original manner the beginning of the Augustus' cult with people tired of war and unrest awaiting for a saviour who would bring peace. He claimed that this was the source of honours given to Caesar's successor, e.g. incorporation of his name into religious hymns. As far as his understanding of the role of Augustus in the development of the cult of a ruler in Rome Piotrowicz differs from Zieliński in some ways. The latter saw the roots of the cult of a ruler in the cult of a genius whereas according to Piotrowicz Augustus' reform in $7 \mathrm{BC}$ was only an attempt at connecting the cult of a ruler with the Republican traditions in the least jarring manner, because of an indirect way. Further development was to go along the line that had been long since settled in the Greek East ${ }^{17}$. In relation to Augustus' religious politics Piotrowicz was particular about its duality regarding the popularisation of the cult of a ruler - it took different shapes in the Eastern and the Western part of the Empire. He also pointed out some inconsistencies in the Western part of the

\footnotetext{
${ }^{15}$ L. Piotrowicz, Kult panującego w starożytności, Poznań $1922^{1}, 2006^{2}$. I cited here the second edition.

${ }^{16}$ L. Mrozewicz, Ludwik Piotrowicz, Poznań i kult panującego, [in:] ibidem, p. 16-17. Cf. L. Mrozewicz, Badania nad dziejami Grecji i Rzymu w Poznaniu (1919-2008), [in:] Świat starożytny, jego polscy badacze i kult panującego, ed. L. Mrozewicz, K. Balbuza, Poznań 2011, p. 16-17.

${ }^{17}$ L. Piotrowicz, Kult..., p. 65.
} 
Empire where the living emperor was not acclaimed a god as in Rome but was venerated with divine glory in other parts of Italy ${ }^{18}$.

Another scholar who dealt with the question of the cult of an emperor was Mieczysław S. Popławski (1893-1947), a professor at the Catholic University in Lublin ${ }^{19}$. Unfortunately, this brilliant scholar is somewhat forgotten, even by the Polish historians. Popławski was a very original researcher who combined the achievements of ethnography and anthropology with his excellent historical skills and abilities ${ }^{20}$. He is, inter alia, the author of the long study published in French on Sulla and Augustus' apotheoses in which he dealt with, among other topics, the genesis of the cult of an emperor ${ }^{21}$. Popławski attributed it, just like other scholars, to the Greek East. Strictly speaking, the consecration of Hellenistic rulers was the result of two tendencies: the tradition of heroization in the classical Greece and some forms of the cult of Eastern kings (a classic example is of course the pharaohs of Egypt) who were recognised as revealed gods. In his work he emphasised clear differences between the cult of a ruler in Rome and in Greece. One of the main differences concerned lindividualisme pratique which prevailed in Rome in the last century of the Republic. Therefore he devoted part of his work to the analysis of the sources which have a poetic or philosophical character and which Piotrowicz had thoroughly omitted. Popławski finds Sulla as the first Roman who consciously tried to put himself above other mortals. Hence his nickname Epaphroditus and patronage in the figure of Aphrodite-Venus; however, it concerned Aeneadum genetrix and a mighty deity of Asian origins, the goddess of the earth, people and all life - l'impulsion primordiale et la cause de la vie. Therefore, Sulla seemed to be not a mere mortal who was aware of his inferiority towards the deity but an incarnation of the divine will and, consequently, power. The dictator's will coincided with divine will.

In his study Popławski points out the difference in the way Sulla, Caesar and Augustus treated apotheosis which in short can be defined from the chosen by gods (Sulla Felix) through god (Iuppiter Iulius) to the deified (Divus divi Filius Augustus). He saw the source of the idea of human deification itself partly in the cult of Greek heroes and Hellenistic rulers but also in Caesar and Augustus' legal theory and practice. He also pointed out the natural human tendency to recognize distinguished personalities as divine and to the old traditions giving each ruler a sacral character. He believed that in comparison to the cult of rulers and heroes in Hellenistic societies we could notice in Rome extension and expansion of the

\footnotetext{
${ }^{18}$ Ibidem, p. 65-66.

${ }^{19}$ H. KowalsKi, Lublin ośrodkiem badań nad historia starożytna (1918-2010), [in:] Świat starożytny, jego polscy badacze..., p. 48-49.

${ }^{20}$ E.g. M.S. Pop£Awski, Bellum romanum. Sakralność wojny i prawa rzymskiego, Lublin $1923^{1}, 2011^{2}$. Popławski devoted to Augustus and his age some fragments of his other book which concerned political writing. See IDEM, Polityczna publicystyka $w$ dobie Cezara i Augusta, Lublin 1935, p. 183-238. ${ }^{21}$ IDEM, L'apothéose de Sylla et d'Auguste, E 30, 1927, p. 273-338.
} 
content covered by this term mainly by legal and social aspects. Therefore it can be assumed that Mieczysław St. Popławski saw deified emperors through a transcendent perspective and not in an inherent one as it was in the case of Ludwik Piotrowicz ${ }^{22}$.

Ludwik Piotrowicz was an author of the Polish first modern study book for the Roman history ${ }^{23}$. He devoted its rather big part to Augustus. Piotrowicz drew his attention to the main difference between the aspiration of Octavian / Augustus and his adopted father. In his opinion, Julius Caesar wanted to change the government from republican into purely monarchic. Augustus however started to come back to the republican form and in 27 B.C. he resigned from all his positions. Piorowicz explained that as a result of this move Octavian became Augustus in psychological dimension. For the Polish scholar the first emperor was a person of calm and a stoic mind. In small steps, festina lente, he achieved everything what he had planned. He was not a genius as Caesar or Sulla but through his intelligent and cautious politics he transformed the Roman political system from the model for civitas into a system for the imperium. The novelty that Piotrowicz saw in the Augustus' actions was the concentration of the old republican dignities and entitlements in one hand. From this perspective the emperor appears as a continuator of the well-established tradition but also as sly and calculating politician.

Now let's return to Tadeusz Zieliński and his research. He proposed another understanding of the first princeps' deeds in the field of religion. In his works published during a 40-year period, Zieliński presented an original understanding of the crisis of Republican religion, perceived not in political but in eschatological terms. In other words, the changes in the civic religion in the 1st century B.C. were perceived by Zieliński not in terms of the religious downfall (as Mommsen and Wissowa) but of the fin de Rome, an eschatological spin which he connected with the figure of Sibyl. As I have already mentioned, Zieliński dealt with the question of a sibylline messianism for a long period. For the first time he presented it in Russian in 1899, then in French in the work La Sibylle published in 1924. This version became the basis of the most comprehensive overview of the subject that was published in Polish in the book Religion of the Roman Republic. The chapter included in this work was in turn presented in short in Quaderni Augustei. Studi stranieri VIII titled La sacra missione di Augusto, which was published in $1937^{24}$.

There is a clear shift in the paradigm of the studies on Roman religion, especially in regard to Theodor Mommsen and Georg Wissowa's proposals. A hidden basis for his reflections was the assumption of Zieliński that Christianity was a universal

\footnotetext{
${ }^{22}$ More about emperors' cult can be found in the works of A. Gillmeister, Kult cesarski w polskich badaniach historycznych, [in:] Świat starożytny..., p. 193-203. I resume my research there.

${ }^{23}$ L. Piotrowicz, Dzieje rzymskie, Warszawa 1934.

${ }^{24}$ T. Zieliński, La Sibylle. Trois essais sur la religion antique et la christianisme, Paris 1924; IDEM, La sacra missione di Augusto. Quaderni Augustei. Studi Stranieri 8, Roma 1938. Cf. IDEM, Religia rzeczypospolitej rzymskiej, vol. II, Warszawa 1934, p. 193-309.
} 
model of religious experience, as it stressed the individual and personal contact with God. Zieliński treated ancient religion (he used this term sometimes in a plural and sometimes in a singular form) as a preparation psychologique for Christianity. Tadeusz Zieliński was one of a few researchers of his period who wanted to reject the still picture of ritualised and fossilised Roman religion. He showed it clearly in the analysis of religious transformation at the end of Republic and creation of the Empire. The religious crisis of those times was a fact for him but he saw it in a metaphysical and eschatological perspective and thus the religious politics of Augustus was for him a rebirth and redemption from the annihilation ${ }^{25}$.

Now I would like to focus only on the role which the first princeps played in the model proposed by the Polish scholar. There is no place to make a wider presentation of Zielinski's idea, which after all belongs more to the field of historiosophy than historiography. It is worth noting that Zieliński clearly employed Christianised language, and e.g. used certain typical terminology. He used terms such as la prophet de la Sibylle or péché originel. In regard to the Greek religion, Zieliński used the word prophet in reference to artists such as Praxiteles ${ }^{26}$. Whereas in regard to Rome he used this term referring to Virgil and Horace, whom he called les prophetes de la Sibylle ${ }^{27}$. Let me quote a passage from Zieliński:

\begin{abstract}
Laspect des temps avait changé, et celui de la Sibylle ausi. Lépoque stoïcienne - nous pouvons l'appeler ainsi - ne savait que faire de l'éon d'Héraclite, cet «enfant folâtre, jouant aux dame», la doctrine du Portique, tout en acceptant pour base la physique du philosopje ténébreaux, avait remplace son éon par l'idée de la providence. Le devenir devait avoir une essence morale; or, le fond même de la morale consiste dans l'axiome que tout châtiment a pour cause un délit. Quel était donc le délit qui allait avoir pour effet ce châtiment suprême: l'anéantissement de cette Rome qui était devenue le monde?
\end{abstract}

C’est ici que l'idée du péché originel se présenta au monde antique. Ce nétait pas la premiére fois; on devrait remonter à Anaximandre pour en tracer lévolution. Mais, cette fois, ce péché devait être quelque chose de palpable, un péché originel non pas métaphysique, mais historique..$^{28}$

In the quoted part the most important elements of Zieliński's concept are clearly visible - the wrath of gods, the original sin (Remus' killing) and the threatening danger. In another passage of his study he described the atmosphere of the period of civil wars and everyday terror, which lasted for many years and intensified after Caesar's death ${ }^{29}$. Additionally, various prophecies related to the Sybil's

${ }^{25}$ T. ZielińsKi, La Sibylle..., p. 97-125, IDEM, La sacra..., p. 3-24.

${ }^{26}$ IDEM, The Religion of Ancient Greece, Oxford 1926, p. 67.

${ }^{27}$ Zieliński used this expression many times in numerous places, e.g.: IDEM, Dies irae. Studjum religjonistyczne $z$ antycznych przeddziejów chrześcijaństwa [Dies irea. The religionism study on the ancient pre-Christian times of Christianity] Warszawa 1929, p. 28; IDEM, La sacra..., p. 7.

${ }^{28}$ IDEM, La Sibylle..., p. 121-122.

${ }^{29}$ Cf. IDEM, Horace et la société romaine du temps d’Auguste, Paris 1938, p. 51. 
name started to go the round which raised the question about the time of the known world's end. Calculations depended on the assumption about the Sibylline age - 100 or 110 - and about the point from which the so-called 'year zero' should be counted. However, all the calculations pointed to the second half of the $1^{\text {st }}$ century BC. The Roman world needed a messiah: the child who Virgil referred to in the famous $4^{\text {th }}$ eclogue. So, was young Caesar to be this child - who took on the patron deity Apollo who according to the Sibylline prophecies was to revive the world as the god-protector of the last century? Do we come across something that has to do with the embodiment of a god into a human? Or a human into a god? Nevertheless, as Zieliński wrote, such a merry hearsay" had spread 20 years before Jesus' birth. And it was propagated, despite initial reluctance, by the poets of the Augustan era. Zieliński claimed that the Sibylline prophecies - the term he used to call the whole chain of the consecutive prophecies - gave a religious dimension to the political events which led to the rise of the new regime. Consequently, gratefulness towards the creator of the Principate must have had the same dimension of a religious veneration ${ }^{30}$.

This is the perspective Zieliński took while analysing the foundations of Octavian's authority including the acquisition of the title of Augustus. He claimed that the end of the civil war and the realisation of the Sibylline prophecies signified the beginning of the new era, which in turn demanded new rituals and honouring the saviour. The end of the old era which had begun with Romulus' reign would suggest that the first king's name should be adopted but the sense of odium regni was strong enough among the Roman people for the idea to fail. Therefore the princeps took the title of Augustus as the memento of the first auspices. Zieliński interpreted it as una nuova fondazione della cittá - finora macchkata dal peccato originale - ormai espiata, redenta e pura ${ }^{31}$. The final exoneration of the original fault was the solemn celebration of the beginning of the new era through the observance of Ludi Saeculares. Zieliński gave much attention to the date of these celebrations. A large part of his examination - in every version of the study - is devoted to the determination of the proper date. One cannot dispose of the impression that this outstanding intellectual, a candidate for the Nobel Prize in Literature, a holder of honoris causa doctorates at many universities, an honorary member of numerous academic associations, treated the issue as of fairly poetic character with nearly mystical attitude. It is, to stress it once again, another example of the shift of Zieliński's focus from historiography to historiosophy. In any case, in the Italian

\footnotetext{
${ }^{30}$ About the role of Sibyl in Augustan politics cf.: A. GillmeIster, Sibyl in Republican Rome - literary construction or ritual reality?, [in:] Society and Religion. Studies in Greek and Roman History, vol. III, ed. D. Musią, Torun 2010, p. 9-26 and A. Gillmeister, Cultural Paraphrases in the Roman Religion in the Age of Augustus. The Case of Sibylline Books, AA.ASH 55, 2015, p. 211-222 with an expanded bibliography.

${ }^{31}$ T. ZielińsKi, La sacra..., p. 17.
} 
version of the study on sacred mission of Augustus Zieliński wrote about storiosofia religiosa: Nel centro della storiosofia religiosa dei Romani troviamo la figura e la dottrina della Sibilla ${ }^{32}$.

To sum up this discussion, it is worth noting that for Zieliński the real old testament of Christianity was not Judaism but ancient religion. He claimed that Greek and Roman religion (he used these terms quite freely; although he often highlighted the distinctions between Greek and Roman beliefs it is sometimes difficult to understand which beliefs he meant while he wrote about the ancient religion in a singular form) had prepared the minds of the ancients for the reception of the new religion ${ }^{33}$. He clearly expanded the old concept of praeparatio evangelica with belief that ancient religion was the mother of two 'dogmas', which were fully realised in Christianity. This is a common point of view which Zieliński shared with Cumont. For the latter the oriental cults were also a kind of praeparatio evangelica $^{34}$. Belgian scholar wrote the sentences which could be written by Zieliński: L'esprit religieux et mystique de l'Orient s'était peu à peu imposé à la société entiére, et il avait préparé tous les peuples à se réunir dans le sein d’une Église universelle $e^{35}$.

In Zieliński's case it was the assumption about the incarnation of an eternal divine entity which appeared in Rome in the twilight of the Republic and which led to, as Zieliński said, the sacrilegious cult of rulers. The other dogma concerns the appearance of 'the son of god'. One could distinguish two variations: god-son, that is Apollo, and son-god, that is Hercules. These religious ideas were supposed to lead directly to the Christian messiah, now with his function significantly changed as it intertwined with the Judaic concept. In other words, the idea of the Roman messiah, which to some extent was embodied by Apollo, consisted of his universal character ${ }^{36}$. However, as Zieliński convincingly wrote in the Italian version which is the most recent one:

lo sviluppo della storia dei secoli seguenti ha dimostrato in un modo irrefragabile, che la relazione del «vangelo» della Sibilla con l'imperatore Augusto era stata erronea. Il Salvatore del mondo appari infatii, ed appari presso a poco nel tempo predetto, ma non nella persona del padrone potente del mondo visibile. ${ }^{37}$

\footnotetext{
${ }^{32}$ Ibidem, p. 3.

${ }^{33}$ In a more expanded form: IDEM, Préparation du christianisme dans la religion antique, [in:] IDEM, La Sibylle..., p. 7-16; cf. also IDEM, Erudition und Gefühl, [in:] IDEM, Iresione..., p. 460-479.

${ }^{34} \mathrm{~F}$. Cumont, Les religions orientales dans le paganisme romain, ed. C. Bonnet, F. Van Haeperen, Torino 2009, p. 313-314; D. Praet, Oriental Religions and the Conversion of the Roman Empire. The Views of Ernst Renan and of Franz Cumont on the Transition from Traditional Paganism to Christianity, [in:] Religion and Competition in Antiquity, ed. D. Engels, P. VAN Nuffelen, Bruxelles 2014, p. 304-305.

${ }^{35}$ F. Cumont, Les religions orientales..., p. 314.

${ }^{36}$ T. Zieliński, Le Dieu fait homme et l'homme devenue Dieu, [in:] IDEM, La Sibylle..., p. 17-25.

${ }^{37}$ IDEM, La sacra..., p. 24.
} 
There are two reasons why I have paid so much attention to the ideas of Tadeusz Zieliński. Firstly, because of their unquestionable originality due to which they were recognized in historiography. Secondly, I believe it is worth reminding ourselves some of Zieliński's neglected works in the field of religious studies especially in the context of the recently noticed phenomenon of developing studies on our own identity ${ }^{38}$. With regard to the studies on Roman religion it is enough to mention the monumental edition of Franz Cumont's works ${ }^{39}$ and the studies which were published on the occasion of the $100^{\text {th }}$ anniversary of the first edition of Religion und Kultus der Römer by Georg Wissowa ${ }^{40}$.

To sum up, I would like to devote a few words to the bimillenium of Augustus' birthday in 1937. In comparison to other European countries this anniversary did not evoke much response in the Polish academic world. However, a couple of festive sessions of academic societies took place and the presented papers were published as separate volumes. Two booklets by L. Piotrowicz and M. St. Popławski are worth mentioning, a popular presentation of Augustus' life and achievements ${ }^{41}$. Several texts appeared in newspapers ${ }^{42}$ and scientific journals ${ }^{43}$. Only a little engagement was also made on the side of the Italian embassy which took part, mostly indirectly, only in few undertakings ${ }^{44}$. The chronicle published in the Filomata journal, designed then for school students, suggests that the anniversary of Augustus' birthday was noticed and used by the teachers of the classical languages ${ }^{45}$. Filomata was also a place where some of articles related to the anniversary were published. They had popular character but were written by renown scholars and presented a high level ${ }^{46}$.

\footnotetext{
${ }^{38} \mathrm{Cf}$. works cited in note 1.

${ }^{39}$ F. Cumont, Lux perpetua, ed. B. Rochette, A. Motte, Torino 2009; IDEM, Les religions orientales...; IDEM, Les mystères de Mithra, ed N. Belayche, A. Mastrocinque, Torino 2013.

${ }^{40}$ ARg 5, 2003.

${ }^{41}$ L. Piotrowicz, Cesarz August, Kraków 1937; M.S. PopŁawski, Oktawian August, Lublin 1938.

${ }^{42}$ T. Z[Ieliński], Śmierć Augusta [The Death of Augustus], "Gazeta Polska”, nr 14 XI 1936; T. Sinko, 2000lecie cesarza Augusta [Bimillemium of emperor Augustus], "Przegląd Współczesny" 10, 1937, p. 1-19. Four articles were published in PKl 3, 1938: R. Ganszyniec, Posłannictwo Augusta [The mission of Augustus], p. 559-570; H. Markowsкi, Doradcy filozoficzni Augusta [The philosophical advisers of Augustus], p. 571-594; P. Klarfeldówna, Cesarz i poeta [Emperor and Poet], p. 595-634; W. Kozıowski, O wielkości Augusta [On the greatness of Augustus], p. 635-652.

${ }^{43}$ S. Hammer, Oktawian $w$ roli triumwira [Octavianus as triumvir], E 39, 1938, p. 61-81, 191-216; IDEM, 2000lecie cesarza Augusta [Bimillemium of emperor Augustus], E 39, 1938, p. 118-124.

${ }^{44} 23$ April 1937 The Italian Institute in Warsaw organised a lecture about Augustus. The lecture was given by W. Kozłowski and was published in a shorter version in Polonia-Italia 5, 1937. The expanded version: W. KozŁowski, $O$ wielkości...

${ }^{45}$ Fil 95, 1937, p. 187; 97, 1938, p. 293-296 (report on trial on Augustus); 98, 1938, p. 337-338; 99, 1938 , p. 397-338; 105, 1938, p. 186-187.

${ }^{46}$ Fil 84, 1936, p. 99-101; 92, 1937, p. 5-32; 93, 1937, p. 51-67; 99, 1937, p. 99-118; 95, 1937, p. $147-154$.
} 
All these events are linked by one trait. In the Polish historiography of the interwar period which includes works by T. Zieliński, L. Piotrowicz and St. Popławski presented in this paper, the emphasis was clearly put on presenting Augustus as the creator of a new culture, the real father of Empire united under the banner of romanitas and an example of wise ruler who treated his power as a way to be the first citizen and the pater patriae. Not a cruel dictator but a father of European culture $^{47}$. We can also see a strong attempt of the Polish scholars to distance themselves from the celebration of bimillenium of Augustus in Italy by Benito Mussolini. As Tadeusz Sinko stated: what is for Italy a political feast, for other European nations is a feast of culture ${ }^{48}$.

\section{Bibliography}

\section{Literature}

2000lecie cesarza Augusta, E 39, 1938, p. 118-124.

AcCorinti D., Herbert Jennings Rose (1883-1961). The Scholar and his Correspondents, ICS 33/34, 2008/2009, p. 65-107.

AcCorinti D., Raffaele Pettazzoni and Herbert Jennings Rose, Correspondence 1927-1958. The Long Friendship between the Author and the Translator of The All-knowing God. With an Appendix of Documents, Leiden-Boston 2014.

Bonnet C., 'L'Histoire séculière et profane des religions' (F. Cumont): Observations sur l'articulation entre rites et croyance dans l'historiographie des religions de la fin du XIXe et de la première moitié du XXe siècle, [in:] Rites et croyances dans le religions du monde romain. Entretiens sur l'antiquité classique, vol. LIII, Vandoeuvres-Genève 2007, p. 1-28.

Cumont F., Les mystères de Mithra, ed. N. Belayche, A. Mastrocinque, Torino 2013.

Cumont F., Les religions orientales dans le paganisme romain, ed. C. Bonnet, F. VAn Haeperen, Torino 2009.

Cumont F., Lux perpetua, ed. B. Rochette, A. Motte, Torino 2009.

DuRAND J.-L., SCHeID J., "Rites" et "religion”. Remarques sur certains préjugés des historiens de la religion des Grecs et des Romains, ASSR 85, 1994, p. 23-43.

Franz Cumont et la science de son temps, "Mélanges de l'Ecole française de Rome. Italie et Méditerranée", 111.2, 1999.

Frateantonio C., Konzepte der Independenz von Religion, Stadt und Recht bei Theodor Mommsen und Georg Wissowa, ARg 5, 2003, p. 41-46.

Ganszyniec R., Posłannictwo Augusta, PKl 3, 1938, p. 559-570.

Geremex H., Deux lettres adressées à M. Rostovtseff en 1933, DHA 18, 1992, p. 15-25.

Gillmeister A., Cultural Paraphrases in the Roman Religion in the Age of Augustus. The Case of Sibylline Books, AA.ASH 55, 2015, p. 211-222.

\footnotetext{
${ }^{47}$ Cf. M. St. Piotrowicz, Oktawian..., p. 46.

${ }^{48}$ T. Sinko, 2000lecie..., p. 1.
} 
Gillmeister A., Kult cesarski w polskich badaniach historycznych, [in:] Świat starożytny, jego polscy badacze i kult panującego, ed. L. Mrozewicz, K. Balbuza, Poznań 2011, p. 193-203.

Gillmeister A., Sibyl in Republican Rome - literary construction or ritual reality?, [in:] Society and Religion. Studies in Greek and Roman History, ed. D. Musia£, vol. III, Torun 2010, p. 9-26.

Gillmeister A., The Point of View. Tadeusz Zielinski on Ancient Religions, Warsaw 2013 (Akme. Studia historica 11).

Listy do Stefana Srebrnego, ed. G. Golik-Szarawarska, Warszawa 1997.

HAMmer S., Oktawian w roli triumwira, E 39, 1938, p. 61-81, 191-216.

Klarfeldówna P., Cesarz i poeta, PKl 3, 1938, p. 595-634.

Kowalski H., Lublin ośrodkiem badań nad historiq starożytna (1918-2010), [in:] L. MrozewiCz, K. Balbuza, Świat starożytny, jego polscy badacze i kult panujacego, Poznań 2011, p. 47-66.

KozŁowski W., O wielkości Augusta, PKl 3, 1938, p. 635-652.

Markowski H., Doradcy filozoficzni Augusta, PKl 3, 1938, p. 571-594.

Momigliano A., Religious History without Frontiers: J. Wellhausen, U. Wilamowitz, and E. Schwartz, HT 21, 1982, p. 49-64.

Mongolus Syrio salutem optimam dat: La Correspondance entre Mikhaïl Rostovtzeff et Franz Cumont, ed. G. Bongard-Levine, C. Bonnet, Y. Litvinenko, A. Marcone, Paris 2007.

Mrozewicz L., Badania nad dziejami Grecji i Rzymu w Poznaniu (1919-2008), [in:] L. Mrozewicz, K. Balbuza, Świat starożytny, jego polscy badacze i kult panującego, Poznań 2011, p. 15-32.

Mrozewicz L., Ludwik Piotrowicz, Poznań i kult, [in:] L. Piotrowicz, Kult panującego w starożytności, Poznań 2006, p. 11-25.

Piotrowicz L., Cesarz August, Kraków 1937.

Piotrowicz L., Dzieje rzymskie, Warszawa 1934.

Piotrowicz L., Kult panującego w starożytności, Poznań $1922^{1}, 2006^{2}$.

PopŁaWski M.S., Bellum romanum. Sakralność wojny i prawa, Lublin $1923^{1}, 2011^{2}$.

PopŁawski M.S., L'apothéose de Sylla et d'Auguste, E 30, 1927, p. 273-338.

Pop£awski M.S., Oktawian August, Lublin 1938.

PopŁawski M.S., Polityczna publicystyka w dobie Cezara i Augusta, Lublin 1935.

Praet D., Oriental Religions and the Conversion of the Roman Empire. The Views of Ernst Renan and of Franz Cumont on the Transition from Traditional Paganism to Christianity, [in:] Religion and Competition in Antiquity, ed. D. Engels, P. Van Nuffelen P., Bruxelles 2014, p. 285-307.

Les religions orientales dans le mond grec et romain cent ans aprés Cumont (1906-2006). Bilan historique et historiographique, ed. C. Bonnet, V. Pirenne-Delforge, D. Praet, Brussels-Rome 2009.

Santi C., La religione romana negli studi di R. Pettazzoni, SASL 24, 2009, p. 173-188.

S'écrire et écrire sur l'Antiquité. L'apport des correspondances à l'histoire des travaux scientifiques, ed. C. Bonnet, V. Krings, Grenoble 2008.

Severino V.S., La religione di questo mondo di Raffaele Pettazzoni, Roma 2009.

Sinko T., 2000lecie cesarza Augusta, PKl 10, 1937, p. 1-19.

Tadeusz Zielinski (1859-1944). Spuren und Zeugnisse seines Lebens und Wirkens aus süddeutschen Beständen, ed. U. Dubielzig, Toruń 2009.

Tadeusz Zieliński (1859-1944). W 150 rocznice urodzin, ed. E. Olechowska, Warszawa 2011.

Wissowa G., Religion und Kultus der Römer, München $1912^{2}$. 
Z[Ieliński] T., Śmierć Augusta, „Gazeta Polska” 14 XI 1936.

Zieliński T., Cicero im Wandel der Jahrhunderte, Leipzig 1897.

Zieliński T., Das Clauselgesetz in Ciceros Reden, Leipzig 1904.

Zieliński T., Die Gliederung der altattischen Komödie, Leipzig 1885.

Zieliński T., Dies irae. Studjum religjonistyczne z antycznych przeddziejów chrześcijaństwa, Warszawa 1929.

Zieliński T., Der constructive Rhythmus in Ciceros Reden, Leipzig 1914.

Zieliński T., Horace et la société romaine du temps d’Auguste, Paris 1938.

ZiELIŃski T., Iresione tomus II. Dissertationes ad antiquorum religionem spectans continens, Leopoli 1936, p. 111-153.

Zieliński T., La sacra missione di Augusto. Quaderni Augustei. Studi Stranieri 8, Roma 1938.

Zieliński T., La Sibylle. Trois essais sur la religion antique et la christianisme, Paris 1924.

Zieliński T., Mein Lebenslauf - Erstausgabe des deutschen Originals - und Tagebuch 1939-1944, ed. J. Axer, A. Gavrilov, M. von Albrecht, Frankfurt am Main-Berlin-Bern et al. 2002.

Zieliński T., Religia cesarstwa rzymskiego, Toruń 1999.

ZIELIŃski T., Religia rzeczpospolitej rzymskiej, vol. I-II, Warszawa 1933-1934.

Zieliński T., The Religion of Ancient Greece, Oxford 1926.

\begin{abstract}
The figure of the first Roman emperor in many ways had an impact on the Polish culture, especially in historiography and literature. In my paper I focus on some issues connected with the subject. I discuss the ideas presented by Tadeusz Zieliński, one of the most eminent researchers of the ancient world in Europe in the first part of $20^{\text {th }}$ century. He devoted a significant part of his opus to present his own vision of Augustus seen as a reformer of the Roman state religion. Zieliński built the emperor's image as the saviour of the Roman world in the face of „the end of times”. This term played significant role in Zieliński’s thinking about Roman history at the end of the Republic. For the Polish scholar celebration of the secular game in $17 \mathrm{BC}$ was the final task done by Augustus. This task Zieliński defined as the sacred mission and connected with the figure of Sibyl and the impact of the Etruscan theory of saeculum. For Zieliński, Augustus belonged to the most important men of providence in Roman history. In the same way I discuss the ideas presented by Ludwik Piotrowicz and Mieczysław St. Popławski. Both scholars analised the question of imperial cult in depth. Popławski expressed original view on Augustus apotheosis seen as the development of imperial cult in transcendental perspective. Piotrowicz instead saw this problem as a purely political phenomenon. Last part of my paper is devoted to short presentation of the echos of Augustus' bimillenium in Polish scholar activity.
\end{abstract}

Keywords: Augustus' anniversary, Polish historiography, reception of ancient history, Polish scholars of antiquity.

Andrzej Gillmeister

Uniwersytet Zielonogórski

Wydział Humanistyczny

Instytut Historii

al. Wojska Polskiego 69

65-762 Zielona Góra, Polska/Poland

A.Gillmeister@ih.uz.zgora.pl 